\title{
Implementation Of Face-To-Face Online Learning System Based On Audio Video, Presentation And Chat Using The Moodle E-Learning Platform
}

\author{
Erna Budhiarti Nababan ${ }^{1 *}$, Opim Salim Sitompul ${ }^{1}$, Dedy Arisandi ${ }^{1}$, Seniman $^{1}$ \\ ${ }^{1}$ Department of Information Technology, Universitas Sumatera Utara, Medan, Indonesia \\ *Email: ernabrn@usu.ac.id
}

\begin{abstract}
Currently, the implementation of teaching and learning at SMP Negeri 1 Binjai Kwala Begumit was done in the classroom alternately. However, with the current condition of pandemic covid-19, the learning process no longer carried out fully in schools. The school has not been using information technology in the form of e-learning applications in the teaching and learning process. The school has difficulty in recording the existing teaching and learning process: assignments, exams, assessments, and other activities. Therefore the use of e-learning applications is now very much needed. With existing school facilities, such as internet facilities and the ICT teachers, training in developing and implementing e-learning for teaching staff become the best alternative so that learning process can be done properly.
\end{abstract}

Keywords : e-learning application, teaching and learning process, covid-19 pandemic

\section{Abstrak}

Saat ini pelaksanaan belajar mengajar di SMP Negeri 1 Binjai Kwala Begumitt dilakukan dalam kelas secara secara bergantian. Namun dengan kondisi pandemi Covid-19 saat ini, proses pembelajaran tidak lagi sepenuhnya dapat dilaksanakan di sekolah. Pihsk sekolah belum memanfaatkan teknologi informasi berupa aplikasi e-learning dalam proses belajar mengajar. Sekolah mengalami kesulitan dalam mendata proses belajar mengajar yang ada: tugas, ujian, penilaian dan aktivitas lainnya. Oleh karena itu penggunaan aplikasi e-learning saat ini sangat dibutuhkan. Dengan fasilitas sekolah yang ada, seperti tersedianya fasilitas internet, dan adanya guru TIK maka pemberian pelatihan pembuatan dan penggunaan e-learning bagi tenaga pengajar menjadi alternatif terbaik agar proses pembelajaran dapat dilaksanakan dengan baik.

Kata Kunci : aplikasi e-learning, proses belajar mengajar, pandemi covid-19

\section{PENDAHULUAN}

Sekolah Menengah Pertama (SMP) Negeri 1 Binjai yang beralamat di Jalan S. Parman Kwala Begumit Kecamatan Binjai Kabupaten Langkat didirikan sejak tahun 1983 dan mulai beroperasional pada tanggal 23 Maret 1987. Saat ini SMP Negeri 1 Binjai belum memanfaatkan teknologi informasi dalam bentuk penggunaan aplikasi elearning dalam proses belajar mengajar. Aplikasi elearning belum digunakan sebelumnya karena pelaksanaan belajar mengajar masih dapat dilakukan dengan baik secara langsung di kelas tanpa bantuan aplikasi elearning.

Sejak ditetapkannya status pandemi virus corona 2019 atau Covid-19 oleh Organisasi Kesehatan Dunia (WHO) dan kebijakan pemerintah tentang antisipasi penyebaran lebih luas Covid19 yang mengharuskan sekolah diliburkan dan siswa diharuskan belajar dari rumah maka keberadaan elearning sangat dibutuhkan. Kegiatan belajar mengajar sementara ini tidak dapat lagi dilakukan di kelas sehingga pihak sekolah dan guru mencari solusi agar siswa tetap dapat belajar dari rumah. Penggunaan aplikasi media sosial seperti Whatsapp menjadi pilihan sementara, tetapi proses pembelajaran tidak dapat dilakukan secara optimal karena Whatsapp bukan aplikasi khusus untuk elearning. Pihak sekolah kesulitan dalam mendata proses belajar mengajar yang ada. Mulai 
tatap muka, tugas, ujian, penilaian dan aktivitas lainnya tidak terorganisir dengan baik sehingga penggunaan aplikasi elearning saat ini sudah sangat dibutuhkan.

Teknologi-teknologi yang telah berkembang hingga saat ini mempermudah banyak aktivitas manusia diberbagai bidang kehidupan termasuk bidang pendidikan, salah satunya adalah e-Learning (Hartanto, 2016). Pada dasarnya elearning adalah suatu konsep atau sistem pendidikan yang memanfaatkan penggunaan teknologi informasi dalam proses belajar mengajar. Penggunaan eLearning memfasilitasi siswa agar dapat belajar sesuai dengan kecepatan dan gaya belajarnya masing-masing. Jika terdapat kesulitan, mereka dapat konsultasi kepada dosen maupun temannya melalui forum diskusi online atau chatting (Munir, 2009).

Memanfaatkan aplikasi elearning disaat pandemi covid-19 bukan saja bermanfaat bagi siswa yang belajar dari rumah tetapi juga dapat membangun rasa percaya diri dan kemandirian dari para siswa. Selain itu penggunaan elearning juga memiliki keuntungan belajar menjadi lebih efisien dan pelajaran lebih mudah ditangkap (Cole, 2008).

\section{METODOLOGI}

Kegiatan pengabdian ini Dilaksanakan di Kecamatan Binjai, Kabupaten Langkat, Provinsi Sumatera Utara. Kegiatan pengabdian ini melibatkan mitra pengabdian yaitu Sekolah SMP N 1 Binjai yang berlokasi di Jalan S. Parman Kwala Begumit Kecamatan Binjai, Kabupaten Langkat, Provinsi Sumatera Utara. Untuk menyelesaikan permasalahan yang dialami oleh mitra ini, maka metode pendekatan yang ditawarkan adalah dengan pendekatan User Centered Design. Pendekatan ini dilakukan untuk memfasilitasi pengguna sistem agar dapat menerapkan apa yang mereka inginkan. Aktivitas yang dilakukan meliputi analisis kebutuhan aplikasi, pengembangan aplikasi, pemberian pelatihan kepada seluruh elemen sekolah yang terlibat dalam proses kegiatan pembelajaran (Chan, 2012). Dalam rangka melaksanakan pengabdian kepada masyarakat ini, terdapat tahapantahapan yang dilakukan sebagaimana yang disajikan pada Gambar 2.1.

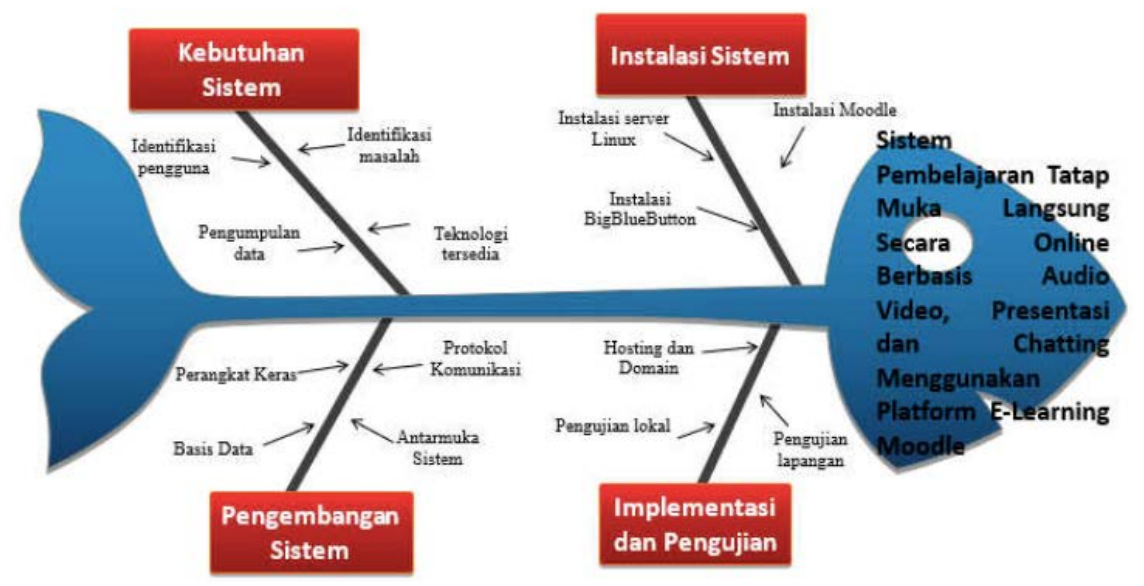

Gambar 2.1. Diagram Fishbone Tahapan Pengabdian kepada Masyarakat

Berdasarkan Gambar 2.1, pengabdian kepada masyarakat yang akan dilakukan terdiri atas 4 (empat) tahapan kerja. Tahapan kerja yang dimaksud adalah sebagai berikut:

\subsection{Analisis Kebutuhan Sistem}

Tahap ini merupakan tahap kerja awal yang dilaksanakan oleh tim pengabdian kepada masyarakat. Tim pengabdian akan melakukan analisis kebutuhan untuk pengembangan sistem dengan cara mengidentifikasi masalah dan pengguna yang nantinya akan menggunakan sistem pembelajaran tatap muka langsung secara online. Pada tahap ini, tim pengabdian kepada masyarakat juga akan 
mengumpulkan data yang berguna untuk mengembangkan fitur sistem elearning yang nantinya diimplementasikan pada sistem. Selain itu, tim pengabdian kepada masyarakat juga mengkaji teknologi komputer baik dari segi perangkat keras dan perangkat lunak terbaru yang dapat mendukung dalam membangun dan mengoptimalkan pembelajaran dengan tatap muka langsung secara online (Aguirre, 2012).

\subsection{Pengembangan Sistem}

Tahap kerja selanjutnya setelah analisa kebutuhan sistem adalah pengembangan sistem. Tim pengabdian masyarakat akan membuat rancangan basis data dan desain tampilan yang akan digunakan pada sistem. Pengembangan sistem juga mencakup perancangan arsitektur perangkat keras server yang mumpuni untuk mendukung sistem, pengkajian dan topologi jaringan komputer dan bandwidth koneksi internet. Selain itu, kajian dan simulasi protokol komunikasi juga dilakukan untuk mendapatkan pilihan protokol komunikasi yang optimal dapat mendukung kegiatan pembelajaran tatap muka langsung secara online (O’Neill, 2004). Serangkaian pemprograman juga akan dilakukan pada tahap ini untuk penyesuaian kebutuhan dan fitur.

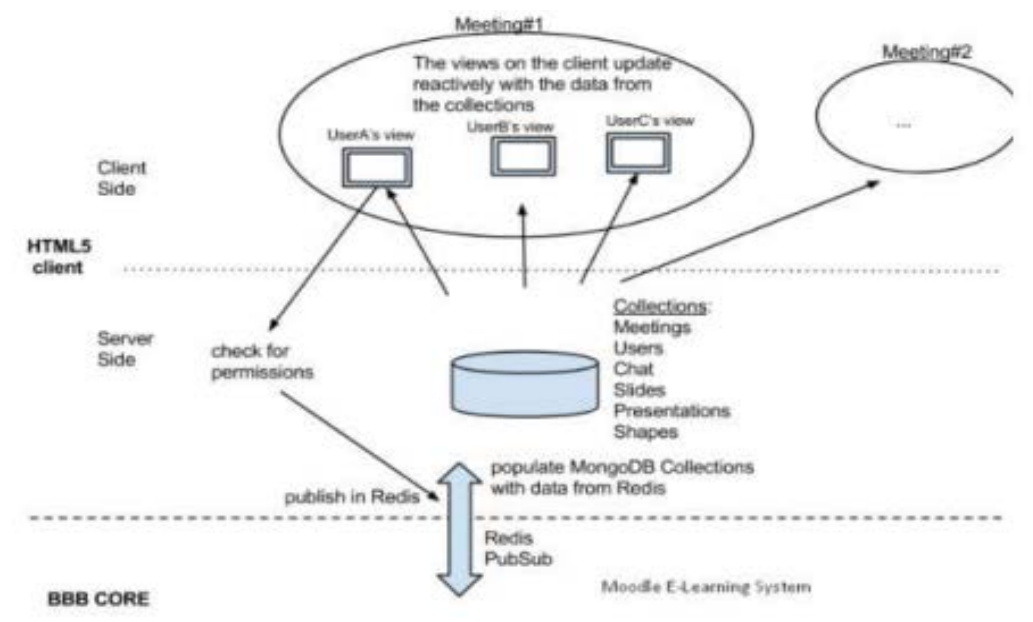

Gambar 2.2. Desain dan Arsitektur Pembelajaran Tatap Muka Langsung Online

\subsection{Instalasi Sistem}

Tahap kerja ketiga pada pengabdian kepada masyarakat adalah Instalasi Sistem. Tim pengabdian akan melakukan instalasi sistem antara lain instalasi server linux, instalasi elearning Moodle (Syamsul, 2019) dan Instalasi plugin BigBlueButton. Plugin BigBlueButton (umumnya disingkat BBB) merupakan komponen penting dalam sistem elearning untuk mendukung dan memfasilitasi tatap muka langsung secara online antara guru dan murid-muridnya. Fitur BigBlueButton yang akan diinstalasi antara lain mencakup audio, video, presentasi, chatting, berbagi layer dan survey. 


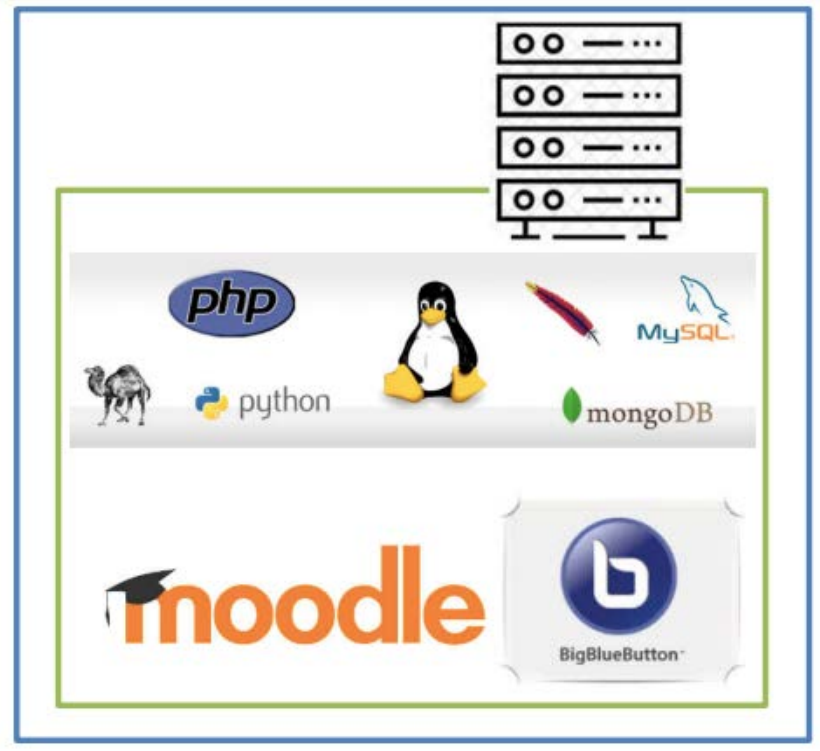

Gambar 2.3. Arsitektur dan Instalasi Sistem

\subsection{Implementasi dan Pengujian}

Tahap kerja akhir dari kegiatan pengabdian kepada masyarakat adalah Implementasi, Pengujian dan Evaluasi. Sistem akan diimplementasikan secara mandiri pada server Domain dan Hosting sehingga dapat diakses secara real time oleh para pengguna. Kemudian tim pengabdian masyarakat akan mengadakan pelatihan kepada semua pihak yang terkait dengan sistem pembelajaran pada sekolah. Selain itum juga akan dilakukan evaluasi sistem dan akan dilihat kinerja sistem apakah mudah dimengerti dan dapat digunakan serta dipahami dengan baik penggunaannya. Dan dapat mengakomodir dengan optimal kegiatan pembelajaran tatap muka langsung secara online. Evaluasi juga dilakukan terkait dengan kinerja sistem berupa kecepatan, keamanan, integritas dan kredibilitas data untuk kenyamanan dalam mengakses sistem.

\section{HASIL DAN PEMBAHASAN}

Hasil yang diperoleh dalam kegiatan pengabdian masyarakat ini merupakan aplikasi sistem pembelajaran online e-learning Moodle yang digunakan pada SMP Negeri 1 Binjai Langkat. Sistem yang digunakan ini dapat membantu sekolah terutama guru dan siswa dalam melaksanakan kegiatan pembelajaran secara online dalam masa pandemi covid-19 yang tengah dialami masyarakat Indonesia. Dengan sistem pembelajaran ini, pencatatan materi pelajaran dan dokumentasi bahan ajar dapat tersusun secara sistematis dan jelas, sehingga para siswa dapat lebih mudah memahami materi pelajaran yang diberikan secara online.

\subsection{Proses Registrasi Domain Halaman Web}

Untuk membangun halaman web pembelajaran berbasis online dengan Moodle diperlukan suatu alamat domain halaman web. Tentunya untuk institusi sekolah sebagai mitra dalam kegiatan pengabdian masyarakat ini lebih cocok dan sesuai menggunakan alamat domain .sch.id. Berdasarkan diskusi yang telah dilaksanakan oleh tim pengabdi dengan pihak sekolah, telah diusulkan domain web sekolah dengan nama smpnegeri1binjai-langkat.sch.id. Sementara untuk persyaratan yang diperlukan untuk pengajuan alamat domain web .sch.id antara lain : - Scan KTP Penanggung Jawab - Scan Surat Permohonan Kepala Sekolah - Scan Surat Kuasa Kepala Sekolah kepada penanggung jawab untuk pendaftaran nama domain Semua persyaratan telah dilengkapi oleh pihak sekolah, dan tim pengabdi telah berhasil mengajukan permohonan pengajuan alamat domain halaman web pada 
panyedia layanan domain dan hosting Masterweb. Berikut status aktivasi alamat domain halaman web yang telah diajukan.

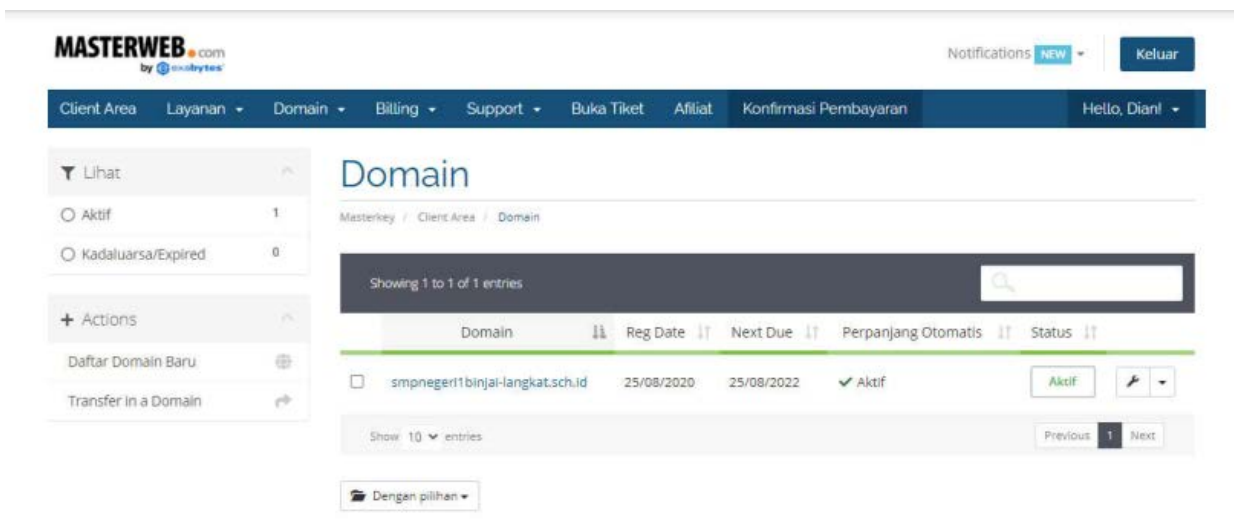

Gambar 3.1. Status aktivasi alamat domain halaman web

Selanjutnya, proses lainnya yang diperlukan adalah pengaturan NameServer untuk pointing ke alamat Server DNS (Domain Name System). Proses ini membutuhkan waktu hingga 1x24 jam.

\subsection{Pengaturan DNS (Domain Name System)}

Pengaturan DNS diperlukan untuk mengarahkan alamat domain halaman web ke Server fisik/virtual (VPS) tempat dimana kode program untuk sistem pembelajaran online di-hosting-kan. Berdasarkan uji coba dan investigasi tim pengabdi, koneksi untuk server DNS server Cloudflare. Berikut pengaturan DNS pada server Cloudflare.

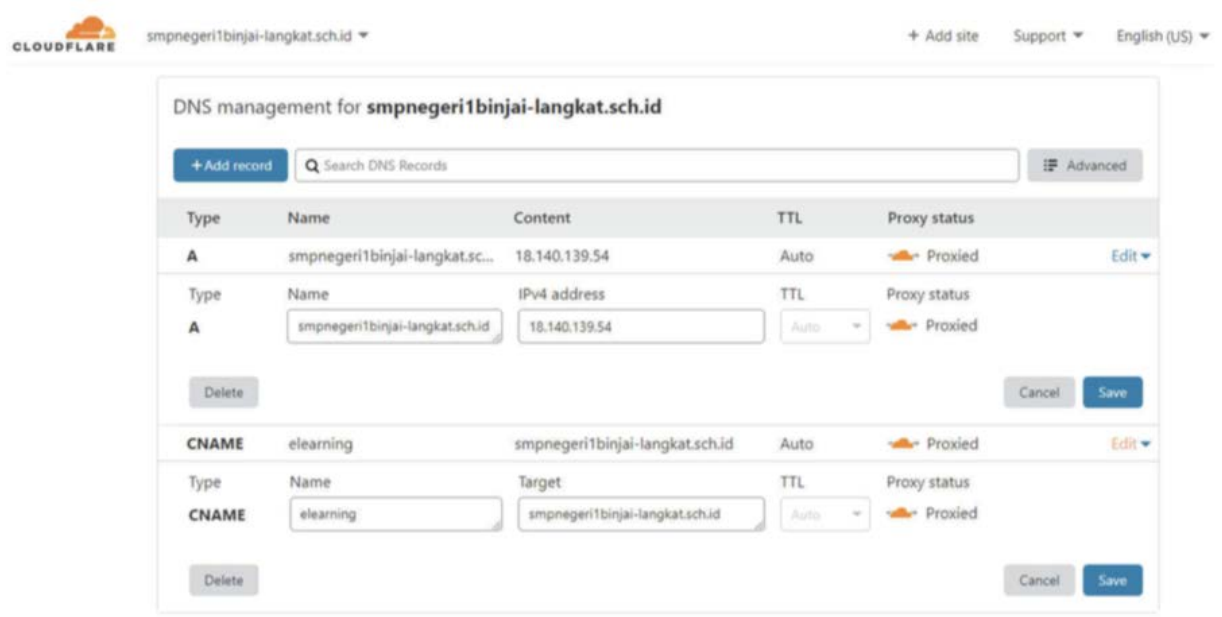

Gambar 3.2. Pengaturan Domain Name System (DNS)

Selain itu, untuk meningkatkan keamanan dalam sistem yang dibangun, tim pengabdi juga telah menerapkan dan mengaktifkan komunikasi HTTPS dan protocol SSL. Dengan sertifikat keamanan tipe SHA2 ECDSA, berlaku untuk satu tahun. Berikut pengaturan pengamanan SSL dan HTTPS pada sistem yang telah dibangun. 


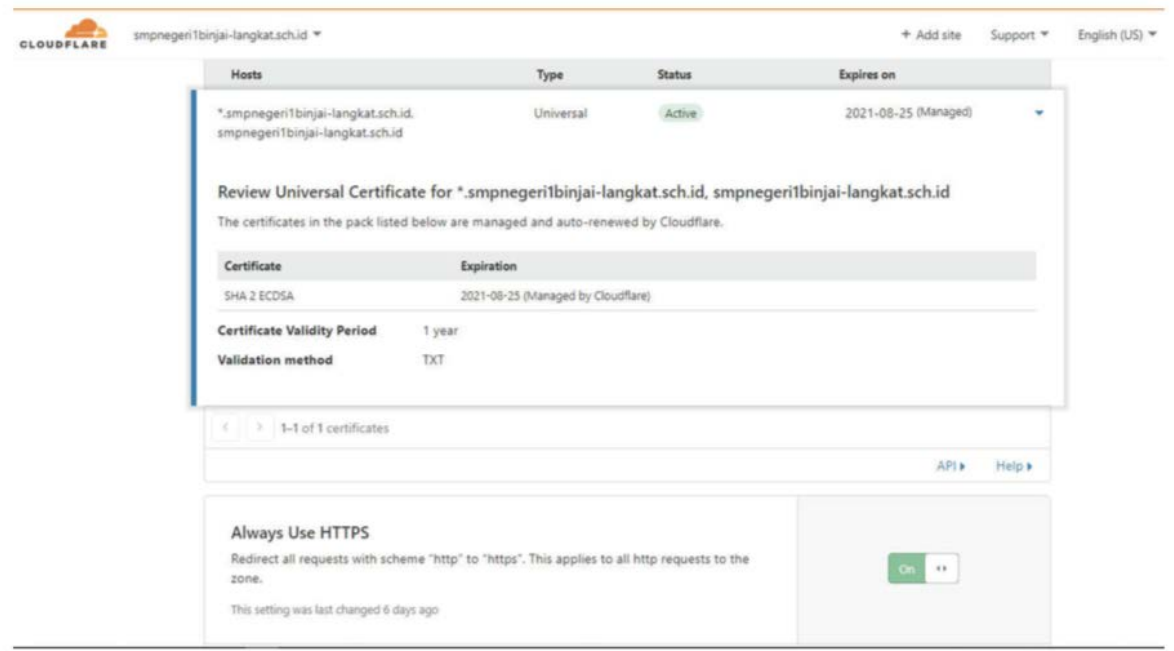

Gambar 3.3. Pengaturan keamanan system dengan SSL dan HTTPS

Dengan pengaturan hingga tahap ini, tim pengabdi telah melakukan pengujian kecepatan akses pada alamat domain halaman web. Pengujian ini mendapatkan hasil yang sangat memuaskan dengan waktu respon yang sangat cepat yaitu hanya mencapai 3 milidetik.

\subsection{Instalasi Sistem Pembelajaran Online Moodle}

Komponen utama dalam kegiatan pengabdian masyarakat ini adalah sistem pembelajaran online. Tim pengabdi telah menentukan untuk membangun sistem pembelajaran online menggunakan platform Moodle yang diinstalasi pada server VPS EC2 dan penyimpanan basis data RDS PostgreSQL. Instalasi moodle dilakukan dalam beberapa tahap yaitu instruksi pada console command prompt VPS EC2, instalasi Moodle pada browser dan konfigurasi admin Moodle.

a. Script instalasi pada console VPS EC2

Berikut perintah yang dieksekusi pada console VPS EC2.

Wget https://download.moodle.org/stable39/moodle-latest-39.tgz sudo tar -C /var/www/html -zxvf moodle-latest-39.tgz

b. Instalasi Moodle pada browser

Berikut tahapan instalasi Moodle pada browser.

c. Konfigurasi Admin Moodle

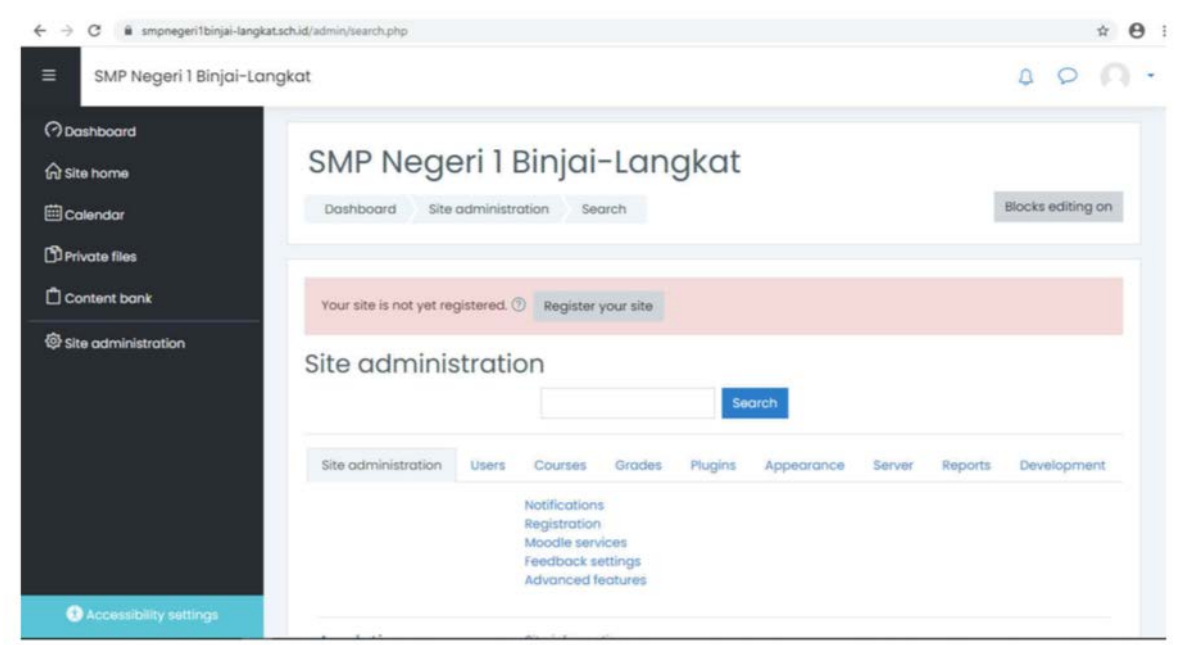

Gambar 3.4. Sistem pembelajaran Moodle yang berhasil di install 


\subsection{Pengelolaan dan Penggunaan Sistem Pembelajaran Online Moodle}

Pada kegiatan akhir pengabdian masyarakat yang telah dilakukan oleh tim pengabdi, terdapat beberapa program dalam pengelolaan dan penggunaan sistem pembelajaran online moodle yang telah berhasil dilaksanakan oleh tim pengabdi. Program tersebut antara lain penambahan pengguna baik guru dan siswa, pengelolaan kategori dan mata pelajaran, penambahan guru dan siswa pada mata pelajaran, penambahan bahan ajar pada sistem elearning, hingga tahap akhir yang merupakan bagian terpenting dalam kegiatan pengabdian ini yaitu program tatap muka online secara langsung. Selanjutnya pada gambar 3.5 dan 3.6 disajikan informasi terkait akun pengguna baik guru dan siswa pada sekolah mitra SMP Negeri 1 Binjai-Langkat. Tim pengabdi telah berhasil menambahkan data tersebut pada sistem elearning moodle berdasarkan data yang telah diberikan pihak sekolah.

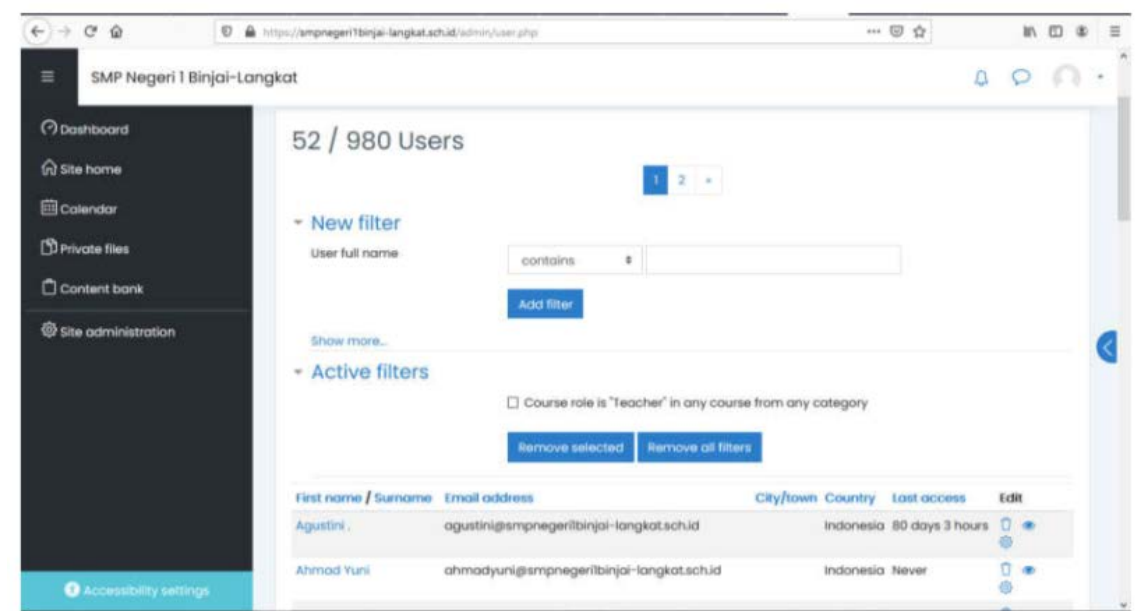

Gambar 3.5. Penggunaan data guru dalam elearning

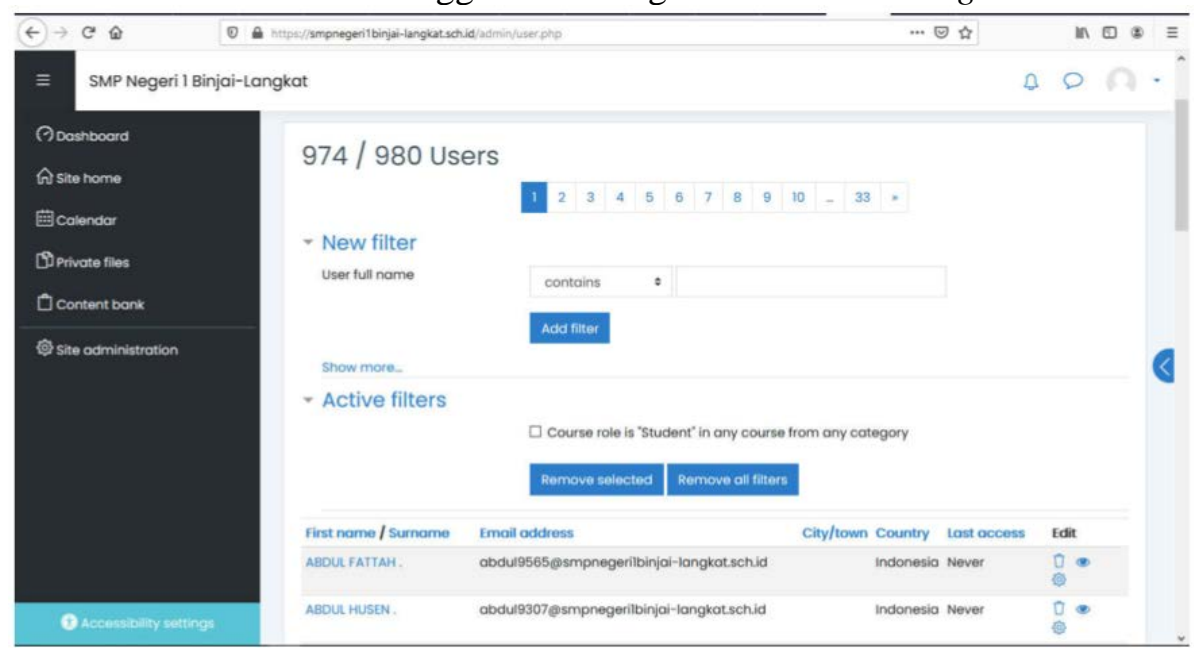

Gambar 3.6. Pengguna data siswa dalam elearning

Proses penambahan data siswa ini, untuk selanjutnya perlu dilakukan tiap tahun ajaran baru, yaitu dengan adanya penambahan murid-murid baru pada sekolah mitra.

Tim pengabdi kemudian melakukan penambahan kategori dan mata pelajaran yang sedang diajarkan pada semester berjalan pada Kelas VII (Gambar 3.7). Kategori yang dibuat juga dibuat untuk Kelas VII, Kelas VIII dan Kelas IX pada tahun ajaran 2020. 


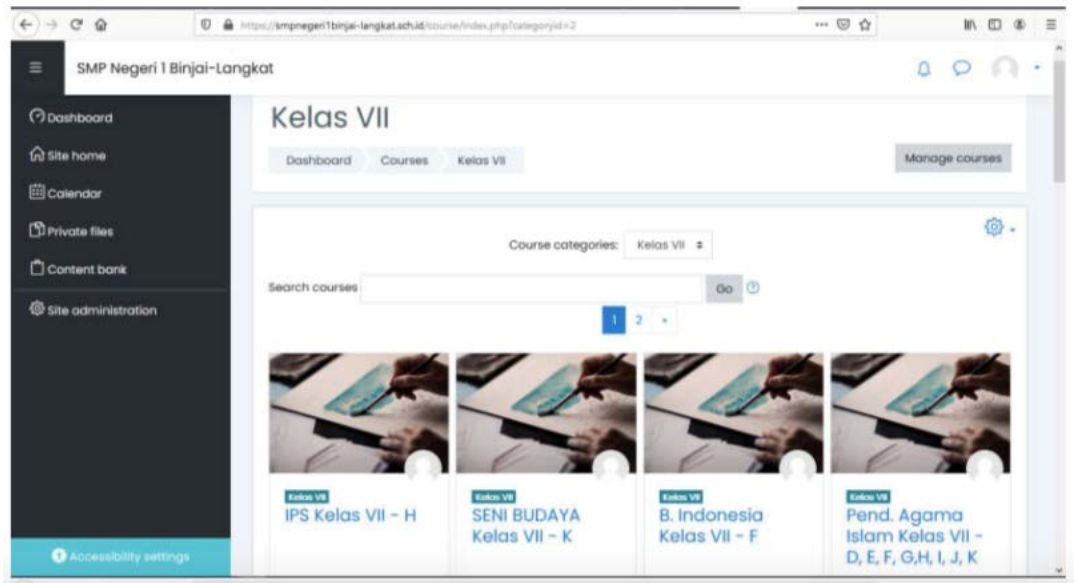

Gambar 3.7. Penambahan mata pelajaran pada Kelas VII

Selama kegiatan pelatihan yang telah dilaksanakan oleh tim pengabdi di sekolah mitra SMP Negeri 1 Binjai-Langkat, tim pengabdi telah memberikan materi dan pembelajaran kepada administrator dan para guru terkait penggunaan sistem pembelajaran daring (elearning). Hal terpenting yang telah diberikan dan diajarkan oleh tim pengabdi antara lain tentang pengisian dan penambahan materi pelajaran pada sistem pembelajaran daring (lihat Gambar 3.8).

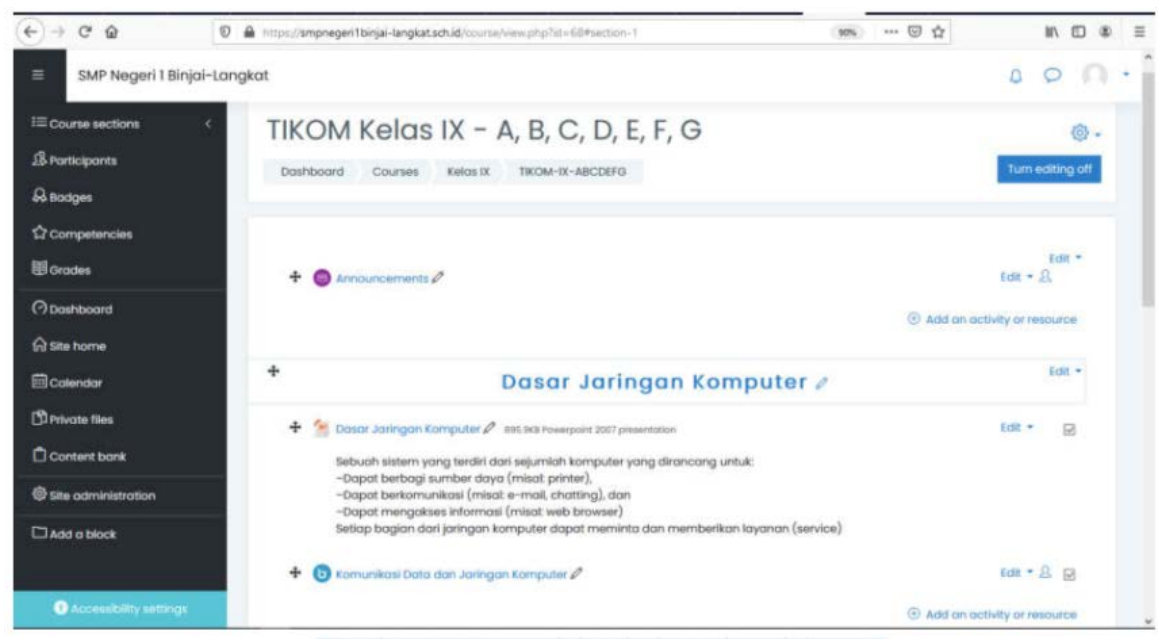

Gambar 3.8. Pengisian bahan ajar oleh guru

Tim pengabdi pada akhirnya telah berhasil membangun sistem tatap muka daring secara langsung untuk pelaksanaan pembelajaran. Dan sistem ini dapat langsung digunakan dan dimanfaatkan oleh para guru dalam menyampaikan materi kepada para siswa. Tim pengabdi juga telah berhasil menguji coba dan mengajarkan kepada guru-guru terkait fitur-fitur dalam sistem ini. Fitur- fitur tersebut antara lain tatap muka daring dengan web camera dan mikrofon, penambahan bahan/dokumen presentasi, chatting dengan para siswa, perekaman sesi pembelajaran, berbagi layar kepada para siswa dan fitur papan tulis.

\section{KESIMPULAN}

Kegiatan pembelajaran yang menggunakan e-Learning dapat meningkatkan efektifitas dan efisiensi kegiatan pembelajaran. Mengapa efektif? Karena dengan bantuan e-Learning, penerapan prinsip 
pembelajaran menjadi lebih mudah. Lalu mengapa efisien? Karena dengan berbagai keuntungan yang ditawarkannya kita dapat menghemat waktu pembelajaran di kelas. Selain itu, dengan eLearning juga kita telah selangkah maju mengikuti arus perkembangan teknologi. Meskipun kita berada di negara yang terdiri dari puluhan pulau dan masih terjebak dalam permasalahan pemerataan pendidikan, tidak ada salahnya jika kita terus berupaya untuk berinovasi dalam pemanfaatan maupun pengembangan teknologi yang kian hari makin canggih. Terlebih jika kita berada di kota-kota besar dimana fasilitas-fasilitas berteknologi mudah ditemukan dan digunakan.

\section{UCAPAN TERIMAKASIH}

Kegiatan Pengabdian Kepada Masyarakat ini dapat teraksana berkat bantuan dana NON PNBP Universitas Sumatera Utara sesuai Kontrak Pelaksanaan Program Pengabdian Kepada Masyarakat Program Mono Tahun Reguler Tahun Anggaran 2020 dengan nomor kontrak 287/UN5.2.3.2.1/PPM/2020, Tanggal 9 Juni 2020.

\section{DAFTAR PUSTAKA}

Aguirre S. \& J Quemada. 2012. e-learning systems support of collaborative agreements: a theoretical model. Educational Technology \& Society Journal, 15 (4):279-295.

Chan. 2012. An innovative learning approach: integrate peer-to-peer learning into blended learning. International Journal of Global Education 1 (1):19-25.

Cole J \& H Foster. 2008. Using Moodle. San Fransico: O’Reilly Media.

Hartanto, Wiwin. 2016, Penggunaan E-Learning Sebagai Media Pembelajaran, Jurnal JPE: Universitas Jember.

Munir. (2009). Pembelajaran jarak jauh ber-basis teknologi informasi dan komunikasi. Bandung: Alfabeta.

O’Neill K, G Singh \& JO’Donoghue. 2004. Implementing e-learning programmes for higher education: a review of the literature. Journal of Information Technology Education 3 (1):313323.

Rizal, Syamsul. 2019. Pembuatan Media Pembelajaran E-Learning Berbasis Moodle pada Mata Kuliah Pengantar Aplikasi Komputer Universitas Serambi Mekkah, Banda Aceh: Jurnal Ilmiah Didaktika. 